\title{
THE USE OF TITANIUM MESH FOR DEFECT CLOSURE AFTER POSTERIOR SPINAL DECOMPRESSION
}

\author{
USO DE MALLA DE TITANIO PARA EL CIERRE DE DEFECTO DESPUÉS DE LA \\ DESCOMPRESIÓN POSTERIOR DE LA COLUMNA
}

\section{USO DE MALHA DE TITÂNIO PARA FECHAMENTO DE DEFEITO APÓS A DESCOMPRESSÃO POSTERIOR DA COLUNA}

\author{
Abakirov Medetbek, ${ }^{1,2}$ Alekhin Alexander, ${ }^{1}$ Nurmuhametov Renat, ${ }^{1}$ Semenistyy Anton ${ }^{3}$ \\ 1. Central Clinical Hospital of Russian Academy of Science, Moscow, Russia. \\ 2. Russian University of Peoples Friendship, Moscow, Russia. \\ 3. Russian Medical Academy of Continuous Professional Education, Moscow, Russia.
}

\begin{abstract}
Objective: The number of revision surgical interventions for degenerative spine disorders has increased steadily. However, the formation of adhesions is one of the more serious conditions accompanying this type of surgery. There are some generally accepted options for its prevention, such as delicate surgical technique, preserving the integrity of spinal canal, and the use of different synthetic materials in the form of gels, plates and membranes to delimit the dural sac from the surrounding soft tissues. The main disadvantages of the described methods are their high cost and the need for a large volume of material in prolonged surgical interventions. Therefore, the development of new methods for prevention of adhesions formations is of paramount importance. The use of titanium mesh is, potentially, an effective and relatively cheap method of preventing the formation of adhesions in spinal surgeries. Methods: We have prospectively analyzed the outcomes of treatment of 40 patients suffering from degenerative spine disease who underwent surgical intervention with titanium mesh implantation in our department between October 2017 and December 2017. Conclusion: The results of our study led us to conclude that the use of titanium mesh enables the surgeon to delimit the dural sac in multilevel spinal decompression surgeries, contributing to closure of the defect in spinal canal and significantly reducing treatment costs. Level of evidence III; Control Case Study.
\end{abstract}

Keywords: Spinal stenosis; Surgical mesh; Titanium; Spine.

\section{RESUMO}

Objetivo: O número de intervenções cirúrgicas de revisão dos distúrbios degenerativos da coluna está aumentando constantemente. Entretanto, a formação de aderências é uma das condições mais graves que acompanha esse tipo de cirurgia. Existem algumas opções geralmente aceitas para sua prevenção, como uma técnica cirúrgica delicada, a preservação da integridade do canal espinhal e o uso de diferentes materiais sintéticos na forma de géis, placas e membranas para delimitar o saco dural dos tecidos moles adjacentes. As principais desvantagens dos métodos descritos são o alto custo e a necessidade de um grande volume de material em intervenções cirúrgicas prolongadas. Portanto, o desenvolvimento de novos métodos para a prevenção de formações de aderências é de suma importância. O uso da malha de titânio é, potencialmente, um método efetivo e relativamente barato de prevenir a formação de aderências nas cirurgias da coluna. Métodos: Analisamos prospectivamente os desfechos do tratamento de 40 pacientes com doença degenerativa da coluna vertebral e que passaram por uma intervenção cirúrgica com implante de malha de titânio no nosso departamento entre outubro de 2017 e dezembro de 2017. Conclusão: Os resultados do nosso estudo levaram-nos a concluir que o uso da malha de titânio permite que o cirurgião delimite o saco dural em cirurgias de descompressão da coluna em multiníveis, contribuindo para o fechamento do defeito no canal espinhal e, significativamente, reduzindo o custo do tratamento. Nível de Evidência III; Estudo de Caso Controle.

Descritores: Estenose espinal; Telas cirúrgicas; Titânio; Coluna Vertebral.

\section{RESUMEN}

Objetivo: El número de intervenciones quirúrgicas de revisión de los procesos degenerativos de la columna está aumentando constantemente. Entretanto, la formación de adherencias es una de las condiciones más graves que acompañan a este tipo de cirugía. Existen algunas opciones generalmente aceptadas para su prevención, como una técnica quirúrgica delicada, la preservación de la integridad del canal espinal y el uso de diferentes materiales sintéticos en forma de geles, placas y membranas para delimitar el saco dural de los tejidos blandos adyacentes. Las principales desventajas de los métodos descritos son el alto costo y la necesidad de un gran volumen de material en intervenciones quirúrgicas prolongadas. Por lo tanto, el desarrollo de nuevos métodos para la prevención de formaciones de adherencias es de suma importancia. El uso de la malla de titanio es, potencialmente, un método efectivo y relativamente barato de prevención para la formación de adherencias en las cirugías de columna. Métodos: Hemos analizado prospectivamente los resultados del tratamiento de 40 pacientes con enfermedad degenerativa de la columna vertebral y que pasaron por una intervención quirúrgica con implante de malla de titanio en nuestro departamento entre octubre de 2017 y diciembre de 2017. Conclusión: Los resultados de nuestro estudio nos llevaron a concluir que el uso de la malla de titanio permite que el cirujano delimite el saco dural en cirugías de descompresión de la columna en multiniveles, contribuyendo para el cierre del defecto en el canal espinal y, significativamente, reduciendo el costo del tratamiento. Nivel de Evidencia III; Estudio de caso de control.

Descriptores: Estenosis espinal; Mallas quirúrgicas; Titanio; Columna Vertebral. 


\section{INTRODUCTION}

The number of revision surgical interventions for degenerative spine disorder is increase steadily. Although there is a wide range of methods for preventing the formation of adhesions, decompression and posterior stabilization often result in the development of epidural fibrosis, causing many problems in cases where revision surgery is required. Therefore, the development and implementation of new methods to prevent the formation of adhesions is of paramount importance. Some generally accepted methods include good surgical technique, preserving the integrity of spinal canal, and the use of different synthetic materials such as gels, plates and membranes to delimit the dural sac from the surrounding soft tissues. But these methods have the disadvantage that they require prolonged surgical interventions, involving high costs and large volumes of material. The use of titanium mesh significantly reduces the cost of treatment, allows the dural sac to be isolated in multilevel spinal decompression surgeries, and helps close the defect in the spinal canal resulting from the laminectomy/hemilaminectomy. These benefits make it especially valuable in prolonged decompression interventions.

Degenerative spine disease is the most prevalent condition among all patients in spine surgery. ${ }^{1}$ According to the World Health Organization, up to $85 \%$ of the world's population suffer from a degenerative spine disease, $10 \%$ of them become disabled. The problem of treatment of this degenerative condition has been the subject of many studies conducted in Russia and all over the world. ${ }^{1-5}$

Degenerative disc disease and spinal stenosis are the main causes of low back pain affecting mobility and quality of life, and involve significant financial burden for society. ${ }^{6} \mathrm{~A}$ number of studies comparing conservative and surgical treatment of degenerative spine diseases have shown better outcomes in the surgical treatment group in regard to pain and functional score up to 8 years after surgery.,

Surgical activity in the treatment of degenerative spine disease, including lumbar stabilization, has increased significantly in recent years. ${ }^{7}$ In the USA, from 2000 to 2009 , the level of surgical activity in the treatment of this disease increased by more than $30 \%$, and continues to grow in line with the aging of the world population. According to the literature, more than 300,000 spinal fusion surgeries are performed annually in the United States. ${ }^{8}$

In cases of severe degenerative changes, sequestrectomy or the removal of only a prolapse pulpous core is not an option as it does not stop the segmental degenerative process, which is partly the consequence of changes to the bone and ligament structures caused by rotational and translational instability. In such cases, surgical intervention can further accelerate the degenerative process by creating additional instability., ${ }^{5,-11}$

Surgical intervention on the spine has one main goal: to stabilize the segment of motion. ${ }^{12}$ Stabilization aims to prevent excessive movements, while maintaining a functionally advantageous body position and preventing the development of spine deformities. The choice of appropriate treatment method, in many cases, remains debatable.

According to recent studies, long-term functional outcomes after surgical intervention are better than those after conservative treatment. ${ }^{12,13}$

For many years, posterior spondylodesis has been a generally accepted surgical treatment method for degenerative disease of the spine. Bone fusion eliminates any pathologic movements, thereby removing the source of pain. ${ }^{11,14}$

Decompression of neural structures followed by spinal fusion (with or without hardware fixation) has been considered the "gold standard" in the treatment of degenerative disorders of lumbar spine for the last two decades. ${ }^{15,16}$

Spinal instrumentation has been widely used for several decades to ensure the stability of the spine. With the advent of transpedicular screws, the use of rods has significantly increased. ${ }^{17}$ It is important to note that the use of transpedicular systems provides immediate stabilization. ${ }^{7}$ In modern spine surgery, rods are used to stabilize all segments of the spine - cervical, thoracic, lumbar and sacral. Along with the progress in spine surgery, the industry has also developed rapidly. Various alloys and polymers has been proposed as material for the rods. Needless to say, the main requirements of these materials are high biofunctionality and biocompatibility. ${ }^{12}$

Biofunctionality is the ability of the implant to function properly in the human body. Biocompatibility is the ability of the implant to stay remain in the host, without causing any undesirable local or systemic effects. Biomaterials used for the rods should precisely match certain mechanical criteria: fatigue strength, rigidity, and high resistance to breakage. Biocompatibility includes all the features of the implant associated with its interaction with the host's immune system, which is very sensitive and hostile to foreign structures. Immune system reactions to the implant can lead to degradation of the implant, and in the case of metal implants, corrosion. ${ }^{10}$

The oxide layer of titanium, which makes the implant biologically inert, allows for the use of titanium endoprostheses to restore bone structures in any part of the skeleton. However, long-term observations have shown that over time, this protective oxide layer is broken due to the stress of deforming forces on the endoprosthesis, resulting in the start of corrosive processes. Interstitial fluid penetrates into the micro-breaks formed, leading to active corrosion and destruction of the implant. Thus, the use of a titanium mesh was suggested, to improve the quality of titanium structures (Table 1).

Table 1. Properties of titanium implants.

\begin{tabular}{c|c|c}
\hline Property & Titanium endoprostheses & Titanium mesh \\
\hline $\begin{array}{c}\text { Implantation } \\
\begin{array}{c}\text { Postoperative control } \\
\text { x-ray }\end{array}\end{array}$ & $\begin{array}{c}\text { Very difficult (intraoperative } \\
\text { modeling is not possible) }\end{array}$ & Possible \\
\hline Corrosion resistance & Difficult & Possible \\
\hline Cost & Mild & Mild \\
\hline
\end{tabular}

\section{METHODS}

A total of 40 patients aged 30 to 85 were surgically treated in our hospital between October 2017 and December 2017. Among them there were 20 patients with degenerative spine disease, lumbosacral spondylosis and lumbar disc herniation. A further 20 patients had degenerative spine disease, cervical spondylosis and cervical disc herniation.

All age groups, except for the oldest, had a prevalence of men, which can be explained by heavier physical and static loads on the vertebral column, and the group represented by patients 51-60 years old, in which the ratio of men to women was equal. With further aging, the number of female patients was significantly increased.

Most of patients with degenerative spine disease who underwent surgery were of working age, which undoubtedly highlights the importance of the current study.

All patients underwent surgical intervention: nerve root decompression, laminectomy, anterior spinal fusion with autograft, posterior rigid fixation, posterior spinal fusion with autograft, and implantation of titanium mesh. The skin incision was $6-8 \mathrm{~cm}$ in length, and intraoperative blood loss was 50-100 ml

All patients underwent a standard preoperative examination to assess the general health condition. Laboratory and instrumental examination was performed on an outpatient basis using common methods, including CBC, urinalysis, blood chemistry panel, coagulation test, test for blood infection, chest X-ray, and ECG. In some cases, the examination was supplemented by pulmonary function test, abdominal ultrasound and ultrasonography of the veins in the lower extremity.

The patient's clinical history was collected at admission, and a physical examination performed, including palpation of the abdomen (inguinal region) to determine the size of the hernial defect.

The patients' physical status was determined as grades I-II according to the ASA Physical Status Classification System. A single-dose second-generation cephalosporin was administered intravenously to all patients, 30 minutes prior to surgery.

The early postoperative period was uneventful and the radicular pain syndrome was stopped in all patients. The X-ray on postoperative day 3 showed acceptable implant position without any signs of bone of destruction. All patients were discharged on postoperative days 5-7. 


\section{Surgical technique}

Restoration of the spinal canal walls following decompression surgery enables the dural sac to be isolated from the paravertebral soft tissues while suturing, reducing the risk of adhesion formation, as well as the risk of damaging the dura mater if revision surgery is required. In addition, the anatomic integrity of spinal canal is restored and spatial reconstruction of the posterior and posterior-lateral walls after laminectomy is achieved. The described technique allows a posterior spondylodesis with autograft to be performed at the level of decompression, without the risk of bone fragment migration into the vertebral canal. The introduction of the titanium mesh implant should relieve the pain, and significantly improve the patients' quality of life.

The use of the titanium mesh is anatomically and biomechanically advantageous, as it allows $3 \mathrm{D}$ reconstruction of the spinal canal to be achieved, with restoration of anatomical relationships of tissues at the site of decompression. The inertness of the titanium alloy, and its biocompatibility, justify the use of this implant. Moreover, the use of titanium mesh does not affect the preserved movements in the functional spinal units (FSU) not included in the stabilization.

The procedure for the method is as follows: after performing the decompression and stabilization at the desired level, an implant of the required shape is made from the plate of titanium mesh. The implant is placed in the area of the defect formed during the decompression and fixed by the transosseous sutures. The rigidity of titanium, together with its resilience and plasticity, enable the walls of the spinal canal to be restored, wherein the implant only comes into contact with the paravertebral soft tissues and bone at the site of fixation, without any contact with the dura mater.

The method of preparation and implantation of a titanium mesh is technically not complicated; it does not involve the destruction of any anatomical structures of the spine and it can be widely used not only to prevent adhesion formation, but also to restore the walls of the spinal canal destroyed during decompression.

\section{Stage 1. Spinal decompression}

The patient is placed in the prone position under the endotracheal anesthesia; the spinous processes are palpated and a posterior midline incision is performed at the desired level. Decortication of the spinous and articular processes and vertebral arches is performed at the required level.

In the case of a disc herniation, laminectomy, hemilaminectomy or facetectomy with radical discectomy is performed to decompress the dural sac and ensure good visualization of the rootlets. Thereafter, the intervertebral interval is processed to the cortical plate, and anterior spinal fusion with autografting is performed.

\section{Stage 2. Posterior rigid stabilization with transpedicular fi- xation system}

Under fluoroscopic or CT guidance, the transpedicular screws are inserted bilaterally. The rod is precontoured according to the lordosis curvature at the level of the fixed segments. The transpedicular fixation system is assembled.

\section{Stage 3. Implantation of titanium mesh, and posterior spinal fusion with autografting}

The appropriate titanium mesh implant is cut out, depending on the size and shape of the defect, and fixed with transosseous sutures at the decompression level. Decortication of the remaining facets and arches is performed, followed by posterior spondylodesis with autografting (Figure 1).

The mean duration of surgery is $70-120$ minutes, depending on the level of decompression.

The length of hospital stay is determined by the attending physician and depends on the patient's general condition. According to our protocols, inpatient rehabilitation is started on the day after surgery. Typically, patients are discharged on postoperative day 5-7.

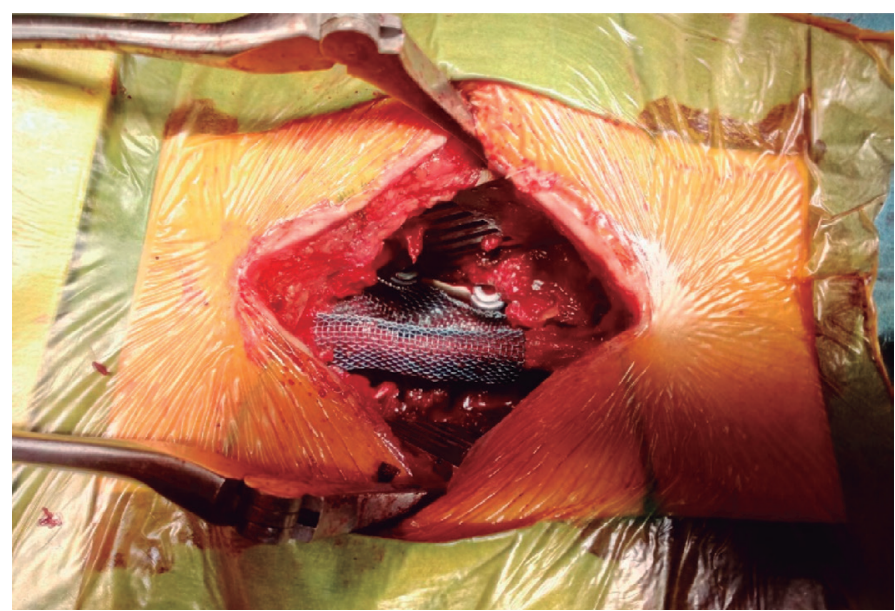

Figure 1. Titanium mesh is placed on the postlaminectomy defect and fixed with transosseous sutures.

\section{Results control}

The results were monitored clinically and radiologically.

In the early postoperative period, the treatment was focused on pain relief, the prevention of peptic ulcers and thromboembolic complications, surgical wound management, dynamic observation, and the start of early inpatient rehabilitation. All patients were discharged home in satisfactory condition.

\section{RESULTS AND DISCUSSION}

This study compares the results of surgical treatment of patients with degenerative lumbar spine disease. The rate of complications associated with the metal implant was considered the main indicator of effectiveness of the described technique with titanium mesh implantation.

The patients included in the study were divided into two equal groups $(n=20)$. In the second group, titanium mesh was used to close the defect formed after posterior spine decompression.

The rate of complications is shown in Table 2 .

There were 6 complications in all: 5 in patients of group 1 and only one in a patient in group 2, in which the titanium mesh was used.

The analysis of complications revealed a significantly greater number of cases of epidural fibrosis in the patients of group 1

Distinctive features of the developed technique for spinal canal restoration after decompression surgery for degenerative spine diseases are not only the possibility of spatial reconstruction of the spinal canal, but also the reduced risk of epidural fibrosis, as it eliminates contact between the dura mater and paravertebral soft tissues.

Due to the fine-mesh structure and porous cover of the composite filament, the implant has capillary properties, which makes it possible to saturate it with antimicrobial solutions in case of infection.

Due to the elastic properties of the titanium wire mesh, and the mutual mobility of the woven threads, it can be easily molded to fit the shape of the convex object it surrounds, contributing to the preservation of the supported organ and increasing safety.

The method used to support the frame is technologically simplified, as it does not require rigid congruence with the topography of the supported soft tissues. In cases of closure of small defects, it was not necessary to fix the mesh as the implant was self-fixed to the edges of the defect when they were covered in the tissue.

In cases of large defects, the mesh was fixed to the edges transosseously with a non-absorbable monofilament suture. This spared intraoperative effect on the soft tissues and promoted their adaptation to the new functioning conditions, improving surgical outcomes and reducing the rehabilitation period.

The use of a titanium mesh implant reduces the cost of treatment, 
allows the surgeon to isolate the dural sac in cases of multilevel decompression, and contributes to the closure of the defect formed after laminectomy/hemilinectomy, especially in prolonged decompression procedures (Figures 2 and 3 ).

Considering that like many other diseases, degenerative lumbar spine disease is occurring in increasingly younger patients, the use of a titanium mesh for defect closure after posterior spine decompression can be a promising technique in the treatment of these patients. It is important to note that even if complications develop, the clinical signs will manifest in remote fashion, maximally increasing the period of social activity and adaptation, without restricting young patients in choosing a profession or practising sports.

Table 2. Outcomes in groups 1 and 2.

\begin{tabular}{c|c|c|c}
\hline Complications / outcomes & Group 1 & Group 2 & $\mathbf{p}$ \\
\hline Pseudoarthrosis & 1 & 0 & $\mathrm{p}=0.08$ \\
\hline Hardware breakage & 0 & 0 & - \\
\hline Hardware instability & 1 & 1 & - \\
\hline Development of epidural fibrosis & 3 & 0 & $\mathrm{p}<0.01$ \\
\hline Overall & 5 & 1 & $\mathrm{p}<0.01$ \\
\hline Duration of hospital stay (days) & $7 \pm 7.3$ & $5 \pm 8.1$ & $\mathrm{p}=0.1$ \\
\hline
\end{tabular}
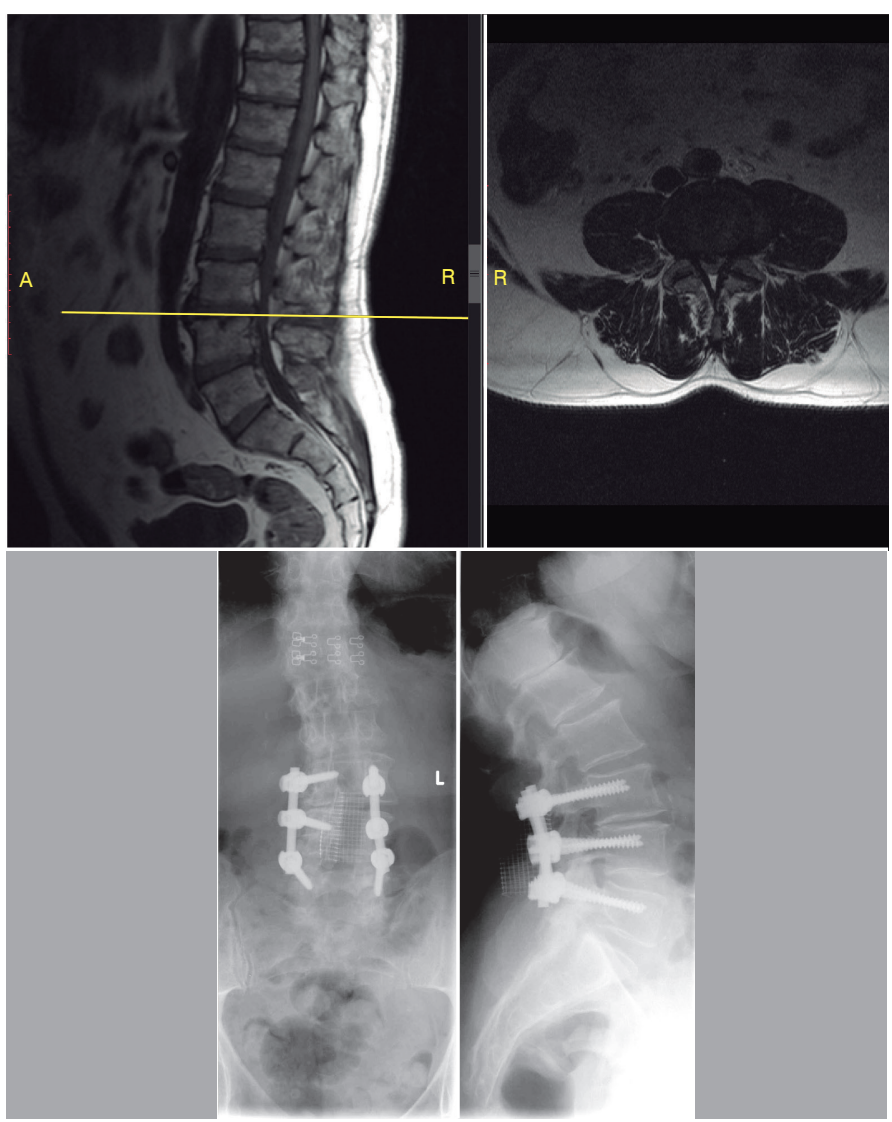

Figure 2. Patient P., 67 years old. Operation: posterior decompression, laminectomy L3-L4, stabilization of L3-L5 with fixation of titanium mesh.
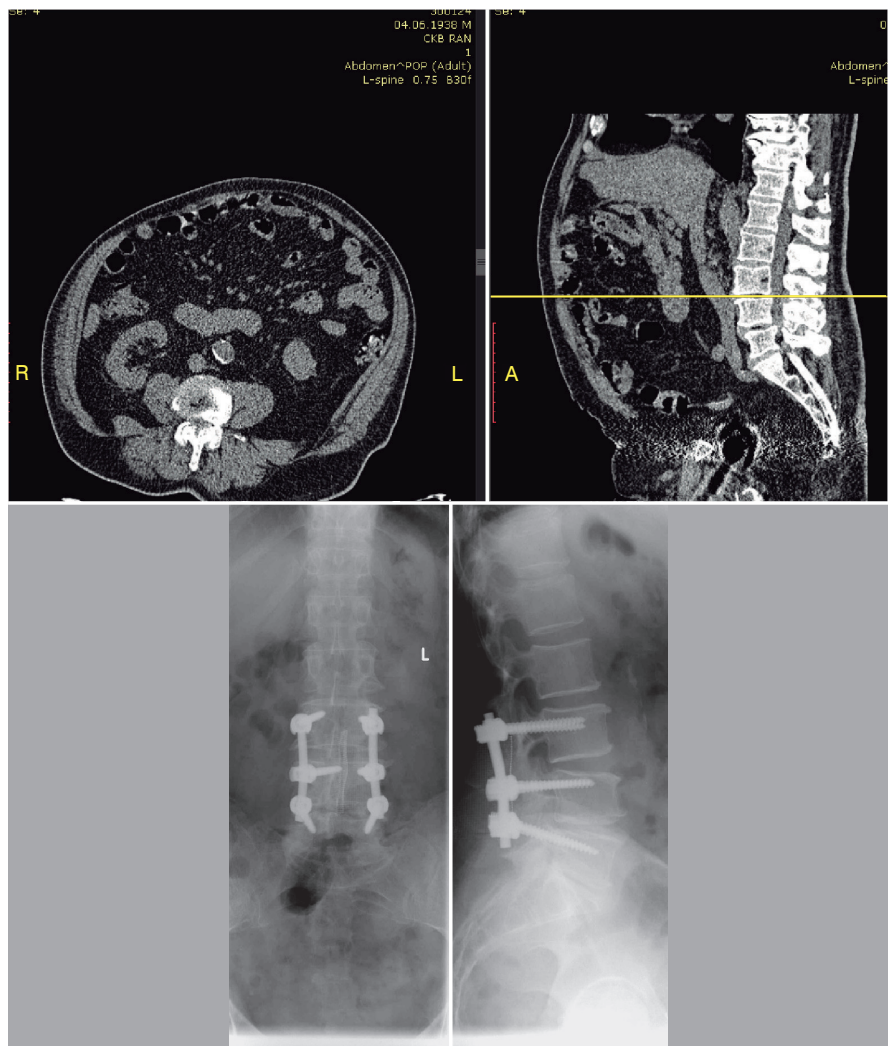

Figure 3. Patient B. 64 years. Operation: posterior decompression, laminectomy L3-L4, stabilization of L3-L5 with fixation of titanium mesh.

\section{CONCLUSIONS}

The use of the titanium mesh implant allows timely prevention of adhesion formation. Based on the results obtained, we can assert that the method is physiological, it combines restoration of anatomical relationships of structures, and at the same time, it isolates the dura mater. Due to the significant decrease in duration of surgery, reduced risk of epidural fibrosis, and the restoration of spinal canal integrity, restoration using the titanium mesh can be considered a technical and economic improvement. There were no cases of epidural fibrosis in patients with the titanium mesh; however further long-term observations are required due to a possibility of developing of this type of complications at later terms. The introduced technique allowed us to achieve the 3D reconstruction of the spinal canal after decompression. The study indicates that the developed technique relieves pain in early postoperative period, reduces the risks of postoperative fibrosis at the decompression site, and closes the defect of the spinal canal. Advantages of the described method are: the implant is selected and installed intraoperatively; the surgery is low-trauma and is accompanied by minimal blood loss; potential pressure of soft tissues on the dural sac is limited; contact between dura mater and paravertebral soft tissues is eliminated; spatial reconstruction of the spinal canal integrity is achieved.

All authors declare no potential conflict of interest related to this article.

CONTRIBUTION OF THE AUTHORS: Each author made significant individual contributions to this manuscript. AM (0000-0002-5842-5904)* is the principal investigator who came up with idea to conduct the current study. AA (0000-0002-3689-921X)*, NR (0000-0001-7155-2062)* and AM took part in all the surgeries, monitored patients and collected clinical data. AA, NR and SA (0000-0002-5412-6202* evaluated the data from the statistical analysis, carried out the bibliographic research and review of the manuscript, and contributed with the intellectual concept of the study. ${ }^{*}$ ORCID (Open Researcher and Contributor ID). 


\section{REFERENCES}

1. Byvaltsev V, Kalinin A, Shepelev V. Unstable forms of degenerative diseases of the vertebral-motor segments of the lumbosacral spine and diagnosis and surgical treatment. Monograph. Novosibirsk, Science 229 pages; 2017. [Article in Russian]

2. Ma D, Liang Y, Wang D, Liu Z, Zhang W, Ma T, et al. Trend of the incidence of lumbar disc herniation: decreasing with aging in the elderly. Clin Interv Aging. 2013:8:1047-50.

3. Lukina E, Kollerov M, Meswania J, Wertheim D, Mason P, Wagstaff $P$, et al. Analysis of Retrieved Growth Guidance Sliding LSZ-4D Devices for Early Onset Scoliosis and Investigation of the Use of Nitinol Rods for This System. Spine (Phila Pa 1976). 2015;40(1):17-24

4. He B, Yan L, Guo H, Liu T, Wang X, Hao D. The Difference in Superior Adjacent Segment Pathology After Lumbar Posterolateral Fusion by Using 2 Different Pedicle Screw Insertion Techniques in 9-Year Minimum Follow-up. Spine (Phila Pa 1976). 2014;39(14):1093-8.

5. Hoff E, Strube P, Gross C, Putzier M. Sequestrectomy With Additional Transpedicular Dynamic Stabilization for the Treatment of Lumbar Disc Herniation: No Clinical Benefit After 10 Years Follow-up. Spine (Phila Pa 1976). 2013:38(11):887-95.

6. Parker SL, Xu R, McGirt MJ, Witham TF, Long DM, Bydon A, et al. Long-term back pain after a single-level discectomy for radiculopathy: incidence and health care cost analysis. J Neurosurg Spine. 2010:12(2):178-82.

7. Guzman JZ, Cutler HS, Connolly J, Skovrlj B, Mroz TE, Riew KD, et al. Patient-Reported Outcome Instruments in Spine Surgery. Spine (Phila Pa 1976). 2016;41(5):429-37.

8. Brox JL, Soresen R, Friis A, Nygaard $\varnothing$, Indahl A, Keller A, et al. Randomized clinical trial of lumbar instrumented fusion and cognitive intervention and exercises in patients with chronic low back pain and disc degeneration. Spine (Phila Pa 1976). 2003;28(17):1913-21.
9. Kepler CK, Vaccaro AR, Hilibrand AS, Anderson DG, Rihn JA, Albert TJ, et al. National Trends in the Use of Fusion Techniques to Treat Degenerative Spondylolisthesis. Spine (Phila Pa 1976). 2014;39(19):1584-9.

10. Mina C, Carreon LY, Glassman SD. Impact of Lumbar Fusion on Health Care Resource Utilization. Spine (Phila Pa 1976). 2016;41(4):353-7.

11. Rahme R, Moussa R, Bou-Nassif R, Maarrawi J, Rizk T, Nohra G, et al. What happens to Modic changes following lumbar discectomy? Analysis of a cohort of 41 patients with a 3- to 5-year follow-up period. J Neurosurg Spine. 2010;13(5):562-7.

12. Reyes-Sanchez A, Zarate-Kalfopulos B, Ramirez-Mora I, Rosales-Olivarez LM, Alpizar-Aguirre A, Sánchez-Bringas G. Posterior dynamic stabilization of the lumbar spine with the Accuflex rod system as a stand-alone device: experience in 20 patients with 2-year follow up. Eur Spine J. 2010;19(12):2164-70

13. Stubbs B. Osteoporosis and falls: Some further considerations for the nursing profession. $\mathrm{Br}$ J Nurs. 2010;19(22):1431.

14. Zu-De Liu, Xin-Feng Li, Lie Qian, et al. Lever reduction using polyaxial screw and rod fixation system for the treatment of degenerative lumbar spondylolisthesis with spinal stenosis: technique and clinical outcome. J Orthop Surg Res. 2015;10:29.

15. Mavrogenis AF, Vottis C, Triantafyllopoulos G, Papagelopoulos PJ, Pneumaticos SG. PEEK rod systems for the spine. Eur J Orthop Surg Traumatol. 2014;24(Suppl 1): $111-6$.

16. Yoshihara H. Rods in spinal surgery: a review of the literature. Spine J. 2013;13(10):1350-8

17. Sengupta DK, Herkowitz HN. Pedicle screw-based posterior dynamic stabilization: literature review. Advances in Orthopedics. 2012 